\title{
Efisiensi Biaya pada Sistem Pertanian Berbasis Zero Waste di Kabupaten Soppeng
}

\author{
Rezky Ramadhani ${ }^{\mathrm{a}, *}$, Vincent Wisnu Sanjaya ${ }^{\mathrm{b}}$ and Wahdina Sukma Rahmawati ${ }^{\mathrm{c}}$ \\ ${ }^{a}$ Politeknik Negeri Ujung Pandang, rezkyramadhani998@gmail.com, Indonesia \\ boliteknik Negeri Ujung Pandang, Vincent.wisnu99@gmail.com, Indonesia

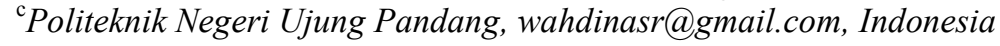

\begin{abstract}
Abstrak. The objective of the research was to know how to calculate Cost Efficiency in a Zero Waste Agriculture System in Soppeng District. The method of purposive sampling was used in research. The data is used in this study consists of prime and secondary data. The prime data consists of observational and interview data directly from a joint group of assisted farmers in Soppeng District, South Sulawesi, who have applied LEISA and as a comparison who have not applied LEISA. The secondary data consists of information about agricultural in LEISA, implementing zero waste in the integration of rice-cattle, sustainable farming systems. The result of this research showed that the utilization of Liquid Organic Fertilizer (POC) and Solid Organic Fertilizer (POP) in planting rice fields proved to be efficient at costs of $4-6 \%$, increasing the number of crops by $12-15 \%$ and quality of crops, besides the use of organic fertilizers can increase soil fertility. Utilization of straw for cattle is proven to streamline costs reaching 4-6\%. Biogas utilization for daily needs can reduce the cost of using LPG gas because it can produce biogas which is equivalent to $3 \mathrm{~kg} /$ week.
\end{abstract}

Keywords: zero waste, leisa, integrasi padi-sapi, biaya

${ }^{*}$ Corresponding author. E-mail: rezkyramadhani998@gmail.com 


\section{Pendahuluan}

Soppeng merupakan salah satu kabupaten dari 24 Kabupaten/Kota di Provinsi Sulawesi Selatan yang beribukota di Watansoppeng Kabupaten Soppeng mempunyai ketergantungan yang besar pada Sektor Pertanian, yaitu sebesar 30,60 persen di samping sektor-sektor perekonomian lainnya. Ketergantungan pada Sektor Pertanian sebesar itu digambarkan oleh kontribusi sektor pertanian terhadap Produk Domestik Regional Bruto (PDRB) pada tahun 2017. Jika dibandingkan dengan keadaan pada tahun sebelumnya mengalami peningkatan karena ketergantungan pada sektor tersebut sebesar 30,26 persen pada tahun 2016. Hal ini berarti bahwa jika sektor ini produktifitasnya baik maka kontribusinya akan memberi dampak positif terhadap kemajuan ekonomi secara keseluruhan.

Pada sektor pertanian integrasi padi-sapi menggunakan model pertanian zero waste, pada dasarnya telah diterapkan oleh beberapa kelompok tani namun belum pernah ada upaya dalam menghitung seberapa besar biaya yang dapat ditekan sehingga diharapkan dapat mengefesienkan biaya dengan pengelolahan limbah yang akan digunakan kembali dalam satu siklus pertanian yang ramah lingkungan dan berorientasi masa panjang.

Berdasarkan uraian di atas, maka penulis tertarik untuk menghitung efesiensi biaya pada system pertanian berbasis zero waste pada sektor peratanian sebagai usaha pertanian berkelanjutan dalam meningkatkan pendapatan masyarakat di Kabupaten Soppeng.

\section{Kajian Literatur dan Pengembangan Hipotesis}

Integrasi Padi dengan ternak sapi berpeluang meningkatkan produktivitas dan mutu hasil Padi. Terdapat sinergi positif dalam pengembangan program pertanian bioindustri berbasis integrasi Padisapi pada agroekosistem sawah irigasi. Produktivitas tanaman akan meningkat baik kualitas maupun kuantitas karena tersedianya pupuk organik yang diproduksi oleh Sapi, dalam hal ini Sapi berperan sebagai industri penyedia pupuk organik baik padat maupun cair. Sebaliknya untuk ternak sapi adanya jaminan ketersediaan suplai pakan yang bersumber dari limbah tanaman padi seperti jerami dan dedak.

Kementerian Pertanian telah meluncurkan Konsep Strategi Induk Pembangunan Pertanian (SIPP) $2013-$ 2045. Hal tersebut sebagai upaya memberikan acuan dan arah pembangunan khususnya di sektor pertanian ke depan. Menurut Suswono (2014a), dengan peluncuran konsep SIPP ini sektor pertanian akan ke arah bioindustri. Implementasi kebijakan ini akan dimulai pada tahun 2014 ini dan akan diteruskan oleh kepemipinan menteri pertanian yang baru.

Sulaiman (2008) mendefinisikan zero waste sebagai "aktivitas meniadakan limbah dari suatu proses produksi dengan cara pengelolaan proses produksi yang terintegrasi dengan minimisasi, segregasi dan pengolahan limbah". Dalam sektor pertanian, zero waste merupakan konsep pertanian yang dirancang untuk para petani agar memanfaatkan pengolahan lahan pertanian sekaligus peternakan tampah limbah.

Untuk menekan pencemaran lingkungan, akan lebih baik jika limbah dapat dikelola menjadi sesuatu yang memiliki nilai tambah ekonomis. Sulaiman (2008) mengatakan bahwa akan lebih baik jika limbah bisa dipandang sebagai bahan baku untuk memproduksi barang tertentu yang tentu bernilai ekonomis.

LEISA (Low Eksternal Input Sustainable Agriculture) merupakan penyangga pola pertanian terpadu. Suryana (2007) menjelaskan bahwa LEISA mengacu pada optimalisasi sumber daya lokal yang ada dengan mengkombinasikan seluruh komponen sistem usaha tani serta menggunakan input luar hanya bila diperlukan untuk melengkapi unsur yang kurang dalam ekosistem. Konsep LEISA yang dilaksanakan akan melahirkan manfaat dan keuntungan, yaitu optimalisasi pemanfaatan sumber daya lokal, maksimalisasi daur ulang (Zero Waste), minimalisasi kerusakan lingkungan (Ramah Lingkungan), diversifikasi produk, sustainable usaha, serta menciptakan kemandirian Suharto (2007).

Penerapan ini selain mengurangi pencemaran lingkungan akibat limbah serta optimalisasi penggunaan limbah, jika dipandang dari perspektif akuntansi pengolaan ini dapat memicu penghematan biaya yang cukup besar karna menggunakan sumber limbah yang pada dasarnya adalah sesuatu yang tidak memiliki nilai ekonomis.

Menurut Mulyadi (2001), Biaya adalah suatu pengorbanan sumber ekonomis yang diukur dalam satuan uang, yang telah terjadi, sedang terjadi atau yang kemungkinan akan terjadi untuk suatu tujuan tertentu. Sedangkan Usry dan Hamer (1991) memberikan pandangan bahwa biaya merupakan suatu nilai tukar prasyarat atau pengorbanan yang dilakukan guna memperoleh manfaat dimasa yang akan datang. Dari definisi diatas disimpulkan bahwa 
biaya adalah suatu pengorbanan ekonomi yang dikeluarkan untuk memperoleh barang atau jasa dimasa sekarang atau yang akan datang.

Dalam konteks pertanian berbasis zero waste biaya yang dimaksudkan adalah seluruh biaya yang dikeluarkan untuk pengolahan limbah pertanian dan peternakan menjadi sesuatu yang lebih memiliki manfaat serta memiliki nilai ekonomis. Setelah melalui pengolahan diharapkan limbah pertanian ini dapat menjadi sumber pakan terna, dan limbah dari peternakan ini dapat diolah menjadi pupuk kompos yang akan digunakan untuk pertanian dan perkebunan serta dapat diolah menjadi bio gas, yakni sumber energi untuk kegiatan petani serta rumah tangga.

\section{Metode Penelitian}

Penelitian ini merupakan penelitian yang menggunakan data-data observasi dan wawancara langsung dari gabungan kelompok tani binaan yang berada di Kabupaten Soppeng, Sulawesi Selatan, yang telah menerapkan LEISA dan sebagai perbandingan yang belum menerapkan LEISA. Waktu penelitian ini akan dilaksanakan pada musim panen yakni sekitar bulan April 2019.

Perumusan model costing dalam penelitian menggunakan model standar pengumpulan biaya produksi berbasis biaya penuh. Teknik pengumpulan biaya ini akan dikolaborasikan dengan teknik kontemporer dengan pendekatan aktivitas yang memberi nilai tambah pada hasil produksi pertanian. Model ini akan dikembangkan menjadi beberapa alternatif seperti halnya model alternatif yang digunakan pada industri-industri yang menerapkan mutu produksi berbasis standar nasional Indonesia. Data-data yang dibutuhkan dalam penelitian ini menggunakan konsep Leisa, mulai dari bibit padi yang kemudian akan diolah sehingga limbah dari padi tersebut menjadi jerami atau pakan. Dari jerami dan pakan tersebut kemudian akan menjadi makanan bagi ternak berupa sapi sehingga akan menambah nilai jual dari ternak tersebut. Kotoran dari ternak tersebut kemudian akan menjadi pupuk cair, pupuk padat dan biogas. Hasil dari pupuk dan biogas tersebut kemudian akan digunakan untuk tanaman padi yang Kemudian akan dijual dan akan menghasilkan uang untuk pembelian bibit padi. Sehingga ini akan menjadi satu siklus sistem pertanian.
Analisis data yang digunakan pada penelitian ini adalah teknik analisis perilaku biaya yang terjadi selama siklus produksi hasil pertanian. Selanjutnya hasil analisis ini akan dikelompokkan berdasarkan klasifikasi biaya secara umum yang meliputi biaya bahan baku, biaya tenaga kerja dan biaya overhead. Biaya-biaya ini akan diformulasikan untuk menghitung harga pokok produksi. Selanjutnya formula produksi yang dikembangkan menjadi beberapa model sesuai dengan alternatif-alternatif atau asumsi-asumsi yang dapat digunakan guna mendapatkan hasil produksi yang maksimal di sektor pertanian berbasis zero waste.

\section{Hasil dan Pembahasan}

Pemanfaatan Pupuk Cair dan Pupuk Padat dalam menanaman Padi

Pengambilan sampel dilakukan dengan asumsi kelompok tani melakukan pengolahan lahan seluas 1 (satu) hectare. Analisis dan pengelompokan biaya produksi sama perhitungan pada komoditi yang lain. Selain itu, peneliti mencoba memisahkan biaya produksi yang dikeluarkan oleh petani yang berbasis LEISA dan yang tidak. Salah satu alasannya adalah pada kelompok tani yang berbasis LEISA menggunakan POP (Pupuk Organik Padat) untuk pengolahan tanahnya dan POC (Pupuk Oranik Cair) untuk pengendalian hama. Berikut adalah ringkasan biaya sebagai berikut:

Tabel 1 HPP Produksi perbandingan Padi non-LEISA dan LEISA

\begin{tabular}{|c|c|c|c|}
\hline \multirow{2}{*}{ No } & \multirow{2}{*}{ AKTIVITAS } & \multicolumn{2}{|c|}{ Perbandingan } \\
\hline & & Non-LEISA & LEISA \\
\hline 1 & Bahan Baku & Rp1.255.000 & Rp1.255.000 \\
\hline 2 & Tenaga Kerja & Rp3.600.000 & Rp3.600.000 \\
\hline \multirow{3}{*}{3} & BOP & & \\
\hline & BOP Tetap & Rp574.750 & Rp574.750 \\
\hline & BOP Variable & Rp14.864.000 & Rp13.124.960 \\
\hline & Total Biaya & Rp20.293.750 & Rp18.554.710 \\
\hline \multicolumn{2}{|r|}{ Hasil Produksi (kg) } & 9800 & 12500 \\
\hline & $\mathrm{HPP} / \mathrm{Kg}$ & Rp2.071 & Rp1.484 \\
\hline
\end{tabular}

Pada tabel tersebut penggunaan POP dan POC dapat menekan biaya variable hingga Rp1.739.040, serta menurut data yang telah diperoleh diatas dengan penggunaan pupuk organik selain lebih murah juga dapat meningkatkan produksi pertanian sampai 2700 kg, karena menggunakan pupuk organik dapat 
memperbaiki unsur hara pada tanah sehingga dapat mencapai pertanian berkelanjutan. Memelihara dan memperbaiki kualitas tanah adalah penting untuk meningkatkan produktivitas pertanian secara berkelanjutan dan kualitas lingkungan bagi generasi yang akan datang. Karbon organik tanah merupakan indikator penting dari kualitas tanah dan keberlanjutan agronomik, karena pengaruhnya terhadap kualitas fisik, kimia dan biologi tanah

Produksi POP dan POC merupakan produk olahan limbah ternak sapi, yakni feses dan urin yang kemudian dimasukkan ke mesin digester, limbah padat dari mesin digester akan ditambahkan promi dan sekam bakar untuk menghasilkan POP yang dapat siap digunakan sebanyak $3700 \mathrm{~kg}$ pupuk sedangkan POC membutuhkan penyaringan selama 3 atau 4 kali kemudian disimpan dalam gentong yang berisi promi dan diputar menggunakan turbin selama 21 hari untuk kemudian siap digunakan dapat menghasil 2400 liter.

\section{Pemanfaatan Jerami untuk Pakan Ternak Sapi}

Adanya anggapan petani selama ini terhadap jerami sebagai limbah padi yang mengganggu dalam pengolahan tanah dan penanaman padi sehingga jerami seringkali dibiarkan membusuk dan harus disingkirkan dari petakan sawah dengan cara yang praktis yaitu membakar. Dengan adanya kegiatan pengolahan limbah sehingga dapat mengubah limbah menjadi pakan yang akan membantu mengefesienkan biaya pada pengembangan sapi.

Tabel 2 HPP Sapi Pengembangan

\begin{tabular}{|l|r|r|}
\hline \multicolumn{1}{|c|}{ Biaya-Biaya } & Non zero waste & Zero Waste \\
& & \\
\hline Sapi bakalan & 11.000 .000 & 11.000 .000 \\
\hline Pakan hijauan/Pakan Ternak & 222.941 & 22.252 \\
\hline Pakan dedak & 955.463 & 250.000 \\
\hline Tetes tebu/Molases & 24.000 & \\
\hline Obat cacing & 900 & 900 \\
\hline Anti Biotik & 1.000 & 1000 \\
\hline Vitamin & 1.875 & \\
\hline
\end{tabular}

\begin{tabular}{|c|c|c|}
\hline Biaya-Biaya & $\begin{array}{l}\text { Non zero } \\
\text { waste }\end{array}$ & $\begin{array}{l}\text { Zero } \\
\text { Waste }\end{array}$ \\
\hline Tenaga kerja & 1.000 .000 & 1.000 .000 \\
\hline Penyusutan Kandang & 125.004 & 125.004 \\
\hline $\begin{array}{l}\text { Penyusutan Mesin Perajang } \\
\text { Rumput }\end{array}$ & 39.996 & \\
\hline Penyusutan Selang Shower & 2496 & 2496 \\
\hline Penyusutan Mesin Pompa air & 8004 & 8004 \\
\hline Biaya Perbaikan Kandang & 20.004 & 20.004 \\
\hline Biaya Bahan Bakar minyak & 17.520 & 17.520 \\
\hline Biaya listrik & 11100 & 11100 \\
\hline Jumlah & 13.430 .303 & 12.460 .155 \\
\hline
\end{tabular}

Pakan ternak yang baik harus mengandung 6-8\% protein dari berat sapi, jerami yang belum diolah memiliki 2-3\% kandungan protein sehingga perlu ditingkatkan dengan cara meng-fermentasikan menggunakan bakteri tripoderma, jamur aspergillus niger dan chrysosporium, urea, garam, molasses, untuk mencapai 6-8\% protein tersebut. Proses fermentasi pakan ternak yakni dengan menumpuk jerami disusun sampai setinggi $20 \mathrm{~cm}$ kemudian menyiram cairan fermentasi kemudian menutupnya dengan terbal, setelah itu ditumpuk kembali, maksimal 3-5 tumpukan keatas.

Pada tabel diatas menunjukkan bahwa penggunakan pakan ternak yang diolah dari jerami dapat menekan biaya sebesar Rp.200.689 serta tidak menggunakan mesin perajang rumput lagi, dedak yang digunakan juga dapat dikurangi dengan menambah volume pakan ternak dari jerami. Sehingga dapat mengefisienkan biaya dalam HPP sapi pengembangan.

\section{Pemanfaatan Biogas untuk kebutuhan Sehari-hari}

Limbah peternakan seperti feses, urin beserta sisa pakan ternak sapi merupakan salah satu sumber bahan yang dapat dimanfaatkan untuk menghasilkan biogas. Biogas merupakan renewable energy yang dapat dijadikan bahan bakar alternatif untuk menggantikan bahan bakar yang berasal dari fosil seperti minyak tanah dan gas alam,

Hasil biogas dari rata $3-5$ ekor sapi tersebut setara dengan gas elpiji $3 \mathrm{~kg} /$ minggu. Dengan 
demikian keluarga peternak yang sebelumnya menggunakan gas elpiji untuk memasak bisa menghemat penggunaan gas elpiji $3 \mathrm{~kg} /$ minggu. Pemanfaatan biogas di Indonesia sebagai energi alternatif sangat memungkinkan untuk diterapkan di masyarakat, apalagi sekarang ini harga elpiji yang makin mahal dan kadang-kadang langka keberadaannya.

\section{Kesimpulan}

1. Pemanfatan Pupuk Organik Cair dan Pupuk Organik Padat dalam menanam Padi terbukti mengefisienkan biaya mencapai 4-6\%, peningkatan kuantitas hasil panen sebesar 12$15 \%$ dan kualitas hasil panen, disamping itu penggunaan pupuk organik dapat meningkatkan tingkat kesuburan tanah.Pemanfaatan jerami untuk ternak sapi terbukti mengefisienkan biaya mencapai 4-6\%, limbah jerami yang dulunya menjadi sampah dapat bernilai ekonomis.

2. Pemanfaatan Biogas untuk kebutuhan seharihari, dapat menekan biaya penggunaan gas elpiji, karena dapat menghasilkan biogas yang setara dengan $3 \mathrm{~kg} /$ minggu

\section{Referensi}

Dede Sulaiman. 2008. ZERO WASTE: Prinsip Menciptakan Agro-Industri Ramah Lingkungan. Jakarta Selatan.

Suryana. 2007. Pengembangan Integrasi Ternak Ruminansia Pada Perkebunan Kelapa Sawit. Juenal Penelitian dan Pengembangan Pertanian. 26(1), hlm 35-40.

Usri, Milton F, W.K Carter \& Lawrence Hammer. 1991. Cost Accounting: Planning \& Control, 10 Edition. Cicinati Ohio: Shout Western

Bps. 2017. Indikator Ekonomi Makro Kabupaten Soppeng. https://soppengkab.bps.go.id (diakses pada 3 Januari 2019)

Suharto. 2007. Peternakan Sapi Perah Dengan Pendekatan Zero Waste dan Zero Cost. Jakarta. 